\title{
The Deployment of Morphological Processes for Socio- Cultural Concepts and Experiences in Educated Nigerian English (ENE)
}

\author{
Steve Bode Ekundayo \\ Department of English and Literature \\ University of Benin \\ Benin City, Edo State \\ E-mail: ekuns20@yahoo.com \\ Patrick Balogun \\ Department of General Studies \\ Federal Polytechnic, Auchi \\ Edo State, Nigeria
}

Received: 13-11-2012

Accepted: 16-03-2013

Published: 01-05-2013

doi:10.7575/aiac.ijalel.v.2n.3p.35

URL: http://dx.doi.org/10.7575/aiac.ijalel.v.2n.3p.35

\begin{abstract}
Educated Nigerians express and store socio-cultural concepts and experiences in various linguistic ways, three of which are examined in this paper: lexicalization, compounding and reduplication. They are conceptualized as intraference in the main because educated Nigerians apply internal linguistic rules arbitrarily, taking a cue from similar instances in the language. This linguistic habit of intraference then works together with contexts and socio-cultural settings to generate intriguing lexical variations. Hence this paper is variationist sociolinguistic. Examples in this paper were gathered through observation, library research, interview, live recording of some linguistic events across Nigeria from 2005 to 2012. The examples of the three morphological processes give ENE some distinctive morphological features. They clearly show how the contexts of use and socio-cultural dynamics constrain educated Nigerians to deploy the extant morphemic and lexico-semantic rules of the language to produce lexical variations.
\end{abstract}

Keywords: Lexicalization, Compounding, Reduplication, socio-cultural concepts, Educated Nigerian English

\section{Introduction}

This paper examines how educated Nigerians deploy the word-formation and lexico-semantic processes of lexicalization, compounding and reduplication to store and transmit socio-cultural concepts and experiences. The creative way in which educated Nigerians deploy the morphological resources of the language to coin words and invest them with peculiar Nigerian and/or universal experiences and meanings generate lexical items that distinguish the morphology of Educated Nigerian English from other (inter)national varieties of English.

Several sociolinguistic factors constrain educated Nigerians to fabricate lexical items in all the varieties of Nigerian English. The desire and necessity to capture and convey peculiar socio-cultural experiences and concepts, creativity as well as the love for variations, the exigency of the moment of linguistic performance, the awareness of usage and individual competence and socio-cultural considerations are some of the extenuating factors that make Nigerians fabricate lexical items that are typically Nigerian.

In a language event, a speaker may not know or may forget the exact word for an idea or something in the target language. Since s/he must share his/her experience or thought, $\mathrm{s} / \mathrm{he}$ then produces an emergency word or phrase, which conveys his/her message at that moment. Thereafter, the new structure may be taken over by members of the audience who then spread it as they move from one place to another. After a period of time, the word (may) become(s) popular and established. Sometimes, educated Nigerians translate and transliterate directly, transferring cultural meanings from Nigerian languages arbitrarily into English words to convey Nigerian ideas, culture and practices (Adegbija, 1989; Ntekim-Rex, 2006).

The habit of forming lexical items through compounding and reduplication is not restricted to ESL settings. It is also common in English as a native language. However, in an ESL situation, as in Nigeria, coinages, compounds and reduplications are deliberately, creatively and sometimes ignorantly produced and invested with meanings. Such formations appear perfectly English at the surface structure, but they convey Nigerian meanings and concepts at the deep structure.

\section{Methodology}

This paper is variationist sociolinguistic of ESL in methodology. Consequently, observation and recording of linguistic 
events and spontaneous speeches were used in the main to gather the examples in this paper from 2006 to 2010 and then updated in 2012 through library research and the Internet. Popular and established cases were extracted from the writings and speeches of national newscasters and prominent members of the Nigerian intelligentsia. Sixty examples are presented in this paper. To establish the popularity or currency of the words among educated Nigerians, they were used to construct sixty pairs of sentences; A is the Nigerian sense and use of the word while B is native English sense and use. The sentences were administered to 10,000 university students and lecturers to tick in ten universities across the six geo-political zones of Nigeria: two universities in Hausa/Fulani North, two in the Middle-belt, two in the Yoruba West, two in the Ibo East and two in the multilingual South-south. Subjects were asked to simply tick $(\sqrt{ })$ correct if they used and knew the meaning of the word underlined in each sentence. Out of the 8,000 collated and analyzed from 2006 to 2012, most of the respondents ticked yes for each sentence. Only second burial and spirit husband scored sixty percent in the North and less than $100 \%$ in some other parts of Nigeria. The sixty words have been annotated in contrast with Standard British and /or American alternatives in this paper.

\section{Definition/Explanation of Terms}

\subsection{Lexicalization}

Lexicalization is the morphological process of coining a lexical item to denote an idea, practice, concept, habit, etc that is often described in long terms. Quirk, Greenbaum, Leech and Svartvic (2003) say that no matter how strange or new it may be, "an entity, or quality can be stated and described in sentences" (p.1525). Subsequently, people find a more precise and economical way of expressing the entity or quality. At the point when a word or phrase is found for the concept or notion, which is often expressed "in sentences and paraphrases, which varied from person to person," then lexicalization has taken place. People lexicalize notions, concepts, abstractions and feelings by using one or more of word-formation and morphological processes: affixation, clipping, blending, borrowing, coinage, calquing, compounding, reduplication and "nicknaming" (Ekundayo, 2011, pp.1-17).

\subsection{Concepts and Conceptualization}

The word concept can be defined from different angles, depending on the field of knowledge. "Philosophers and others generally agree that concepts are formed from experience and other existing mental content by abstraction and other operation in the brain" (Wikipedia, 2012, para.1). The American Heritage Dictionary defines it as "(1) A general idea derived or inferred from specific instances of occurrences. (2) Something formed in the mind, a thought or notion. (3) A scheme, a plan." Elsewhere, concepts are defined as "the constituents of thoughts. Consequently, they are crucial to such psychological processes as categorization, inference, memory, learning and decision" (Stanford Encyclopedia of Philosophy on line). This is the sense in which concept is used in this paper: A concept is one's idea, understanding, outlook and presentation of something and situation. Conceptualization is the human and intellectual habit of putting socio-cultural experiences, abstractions and feelings into concepts. Invariably, concepts and conceptualization are wrapped in words or language, and coinage, compounding and reduplication are some of the ways of expressing concepts.

\subsection{Compounding}

Generally, the term compounding is both syntactic and morphological. Compounding, which is putting two or more grammatical structures together to denote an entity, can occur at the morphemic, phrasal, clausal and sentential levels. For example, You are going and I am going too is a compound sentence. If they come and provided the spirit leads $m e . .$. is a compound clause. The man and his workers... is compounding at phrasal level. Heaven and hell... is compounding at word level. Specifically, however, compounding is often used to denote a morphological formation that has more than one root morpheme or word. It is the "process of combining two words to create a new word (commonly a noun, verb, or adjective)" (grammar. about.com, para. 1).

Quirk et al (2003) say that "a compound is a lexical unit of more than one base... and functioning both grammatically and semantically as a single word. In principle, any number of base may be involved..." and it can occur "within any of the word classes" (p.1568). Examples are headmaster, cover up, officer-in-charge. In terms of orthography, they are written in any of combined/blocked, open/separated and hyphenated forms, as in the three examples above-given.

\subsection{Reduplication}

Reduplication is a kind of compounding because it is a lexical unit of two forms that share orthographic and phonological similarity. According to Crystal (2009), reduplication "is a process of repetition whereby the form of PREFIX/SUFFIX reflects certain phonological characteristics of the root...such as helter-skelter, shilly-shally" (p. 407). In reduplicated structures, two forms that rhyme, or sound alike, or that are identical, are repeated, e.g. hanky-panky, hocus-pocus, jaw-jaw, win-win.

Although we may see reduplication as a type of compounding, they are structurally and semantically different. One difference is that it is often difficult to separate the two forms in reduplication and use them independently as two different words, something possible with a compound word. For example, boyfriend can be separated into boy on the one hand and friend on the other hand. The two are independent and they have different meanings. However, we cannot analyze hanky-panky into hanky- on the one hand and -panky on the other hand, or hocus-pocus into hocus- and -pocus separately. When reduplication is thus cut into two, the reduplicated items lose their essence or sense, unlike in a compound word. 


\section{Theoretical Framework}

This work is variationist sociolinguistic in ESL. It is anchored on four related theories and concepts; namely, William Labov's propositions in his seminal works on variationist sociolinguistics in 1963, 1969, 1972, 1994, 2001 and 2010; Larry Selinker's concept in "Interlanguage" and "The Psychologically Relevant Data of Second Language Learning" (Selinker, 1984, pp. 31-54; 1971, pp.35-43); Jack C Richard's concept of intralingual interference (1984, pp.6-13) and Ekundayo's "Concept of Intraference in English" (2006, pp.6-15; 2012, pp.1-20).

According to Malfet Chomsky (2011), the variationist methodology examines the patterns of language that are variable from speaker to speaker, context to context, setting to setting and from one variety of a language to another. Robert Bayley (2007) captures the nature and focus of variationist sociolinguistic research as follows:

Research in variationist approach, in contrast to research that seeks a single overarching explanation, assumes that interlanguage variation, like variation in any language, is likely to be subject to the influence of not one but multiple contextual influences. That is, variationist research, whether on native or non-native languages, adopts what Young and Bayley (1996) have referred to as the principle of multiple causes (p.135).

(Bold emphasis ours)

Labov (2001) has demonstrated that the forces of language change and variations are embedded in the linguistic system/properties, social and cultural dynamics. The linguistic properties "are in the grammar and they constrain the grammar, and they cannot be described" without reference to the grammar. Further, he asserts that morphological and syntactic variables are informed by "semantic distinctions and/or structural configurations whose development can be traced in the history of the language" (p.84).

Besides the grammar of the language, variationist sociolinguistics, according to Lesley Milroy (2012) makes reference to social (extralinguistic) information in specifying the constraints of variability" (pp.4-5). Accordingly, both linguistic and extralinguistic factors like context of language use, social and cultural constraints, etc work together to engender variations and varieties of a language. The ENE and its morphological features of this study are clear examples of the result of the interplay of linguistic and extralinguistic forces. Naturally placed in a heterogeneous and multicultural second language situation that is far away from a native English setting, educated Nigerians deploy and manipulate the morphological rules of English to fabricate lexical items whose meanings may be peculiar to ESL setting, or are already well-expressed in some other established words in native English usage.

Selinker (1984) says that "interlangauge" is what results from a second language learners' attempted production of a target language norm (TL norm), which is different from the corresponding set of expressions a native speaker of the target language (TL) in the same context may produce. He suggests that "the investigator in the psychology of second language learning can begin to study "the processes that lead to the knowledge behind interlanguage" and "the factors that lead to the knowledge underlying interlanguage" (Selinker, 1971, pp.35, 43). \{Bold emphasis ours\}. Selinker expands "the processes" and "the factors" into five interrelated features: (1) language transfer, (2) transfer of training, (3) strategies of learning, (4) strategies of communication, (5) over generalization of linguistic materials and semantic features.

Different linguists have variously described this fifth phase of interlanguage in long constructs and terminologies. Selinker calls it "the overgeneralization of linguistic materials and semantic features", but Jack C. Richards and Gloria Sampson (1984) variously reduced this long construct to "systemic intralingual errors," "intralingual interference" and "internal language transfer" (pp.6-10). What they denote in various terms is clearly the opposite of interference. This being the case, Ekundayo $(2006,2011)$ lexicalized it as "intraference." By intraference he means the habit of transferring the rules, dynamics and semantic properties of a language from a section where they have been established and where they acceptably operate to another section within the language where they hitherto used not to operate. Since such a transfer is within the language, he lexicalized it as intraference, as the reverse of interference.

Intraference relates to the underlying knowledge which informs the fabrication and use of words by a second language user. Ekundayo's onceptualization of intraference is reminiscent of the foremost linguist Noam Avram Chomsky's (1965) eminent and worthwhile linguistic theorization. However, his concept of intraference is concerned primarily with a language user, particularly a nonnative user, who does not understand his/her second language perfectly and is affected by such socio-psycholinguistically relevant conditions as memory limitations, distractions and shifts of attention and interest. S/he is further affected by the relevant phonological, orthographic, syntactic and semantic rules and exceptions that are characteristic of his second language, as he applies his knowledge in actual performance. In this conceptualization, two major factors that affect the competence and performance of second language users are the psycho-sociolinguistic and the linguistic.

Now, the psycho-sociolinguistic relates to the social knowledge and brain or mind mechanism of the user, the way the user views and rearranges the language creatively or otherwise in his mind as well as the sociolinguistic settings. Precisely, it relates to what Chomsky terms "competence" and "performance." While competence refers to the underlying innate linguistic knowledge of the native speaker, performance denotes the practical, actual use of language in a given situation. As native speakers possess competence so do educated nonnative speakers possess some competence, which is not on par with that of native speakers. However, both the native speaker and the nonnative speaker must necessarily apply their knowledge to perform a linguistic event. Different competences generate different 
performances. Intraference features emanate from the redeployment of the language rules and items that nonnative users know.

The second of the two major factors is linguistic, which is sub-divided into the five main levels of linguistic organization. In effect, intraference manifests at all the levels of linguistics: phonology, orthography, morphology, syntax and semantics. This paper examines some lexical or morphemic examples. The examples demonstrate that the convergence of environment, context and socio-cultural factors constrains nonnative speakers to redeploy morphological rules and processes to create peculiar compound words, reduplications and lexical units that are coded with socio-cultural concepts and experiences in ENE.

\section{1 (Educated) Nigerian English ( $\{E\} N E)$}

Nigerian English is used in this paper to mean the varieties of English used by Nigerians who are literate from primary school to university level. NE varieties are often assessed against the standards of British English (SBE) and/or Standard American English (SAE). Regions, formal education with linguistic features and sociolinguistic parameters are often used to classify NE varieties.

In terms of regions, there exist different varieties of English in Nigeria: Hausa, Yoruba, Ibo, Efik, Urhobo, etc. Each regional variety has its linguistic variations and peculiarities, on the one hand, and similarities to the others, on the other hand. Their differences are most distinct in accent and their similarities are in grammar and semantics.

Several classifications have been made with formal education and linguistic features. Prominent among them are Brosnahan's (1958), Ayo Banjo's (1970; 1996) and Odumuh's (1981) varieties I, II, III and IV (Sunday, 2008, p. 235). Banjo for instance used grammatical features and educational levels for his classification. Accordingly, Variety $I$ is the lowest, which reflects vulgar errors of grammar and broken structures often used by primary school pupils and those with half-baked formal education. Variety II is common with secondary school students and school certificate holders. Variety III is higher standard which is spoken by highly educated people, graduates, teachers, lecturers, senior civil servant, etc. Banjo proposes this model for Standard Nigerian English. Lastly, Variety IV equates native English standard spoken by a few Nigerians who were born in native English-speaking countries or have a parent of English origin and consequently acquire English as their first language (Banjo, 1996, pp. 76-80).

Using sociolinguistic plane, Nigerian linguists often depict three levels or -lects: basilect, mesolect and acrolect. Basilect is a broad-based variety used by a majority of literate Nigerians who may not be so well educated. Between basilect and acrolect is mesolect, which is used by very many Nigerians who have some levels of education and interaction, like secondary school students and certificate holders and those who do not have higher education. Acrolect is Educated or Standard Nigerian English that is used by few people at the highest brackets of education and professions (Igene, 1992, pp.55-123; Ogbulogo, 2005, pp.23-4). The educated variety III of Banjo, which is also acrolect on the sociolinguistic pyramid, is often recommended or preferred as Nigerian standard. It is called Educated Nigerian English (ENE) or Standard Nigerian English (SNE), which has both written and the spoken varieties. The written is much like Standard British English (Jowitt, 2008, p.13) while the spoken is less pedantic and accommodating the features of other close varieties II and I of Banjo's classification as well as code mixing with Nigerian Pidgin and local languages..

On the use of English words to encapsulate meanings, it has been noted that educated Nigerians display the linguistic tendency of stretching the meanings of words beyond their assigned dictionary and native meanings for sociolinguistic, cultural and pragmatic reasons (Adegbija, pp.165-77; Odumuh, 1980, pp. 69-70; Bamiro, 1994, pp.42-61). Neologisms and meaning extension have also been found to be "the defining characteristic" and recurrent features of Nigerian English (Teilanyo, 2008, p.29; Igene 1992, p.36). According to Effiong (2011), Nigerians coin words and expressions which may not have the same meanings in native-English usage. Such linguistic innovations or "semantic contrasts" have made Nigerian English "distinct and unique" (pp. 286-7) Similarly, Osakwe (2011) says that young Nigerians take advantage of Nigeria's complex sociolinguistic background to produce "slangs (sic) and nonstandard usages" showing "semantic drift" (p.33). In this connection, this paper shows that educated Nigerians use lexicalization, compounding and reduplication to encapsulate socio-cultural concepts and experiences.

Human beings intentionally generate and store socio-cultural events and experiences, which are transmitted in words from one person and generation to another. Educated Nigerians express and store socio-cultural concepts and experiences in various linguistic ways, three of which are examined in this paper. They are conceptualized as intraference in the main because intralingual rules are arbitrarily applied, taking a cue from similar instances in the language. This linguistic habit then works together with context and setting to generate intriguing lexical variations. Cases of lexicalization, compounding and reduplication, which emanate from the deployment of morphological processes and the desire to preserve and conceptualize socio-cultural experiences, give ENE some distinctive morphemic features.

\section{Annotation and Discussion of Items}

\subsection{Lexicalization by Affixation, Conversion and Lexico-semantic Extension}

Colomentality (colo- from colonial + mental + -ity)

It is an instance of clipping and blending, which points out a typical African attitude of thinking foreign, behaving foreign, talking foreign and giving superiority and excellence to anything foreign, justifiably or not. Fela Anikulapokuti (1976), a leading African musician of Nigerian provenance, popularized it in his song "colomentality." 
Coined by Fela Anikulapokuti (1978) in one of his songs through the process of back clipping of the word arrangement plus an additional $<\mathrm{e}>$ as in guarantee, refugee, etc, Arrangee means something arranged, organized and executed to deceive. Fela used it derogatorily to denote military rule, which he calls Army Arrangement and arrangee masters. Arrangee is very common in informal Nigerian English and has crept into formal usage as well, usually put in inverted commas in formal writing. It means anything or situation that is fake, deceptive, imagined, etc.

\section{Aristoricism (Aristo+ric+ism)}

It is a coinage from the clipping and blending of a part of aristocrat and the nominal suffix -ism. It is common to see very young girls dating very older and wealthy men, a sugar-daddy-sugar-girl affair. Some modern Nigerian girls have raised this age-long social habit to a sophisticated art, profession or even a 'scientific' sexual business. Aristoricism has been coined to denote this habit of dating aristocrats and very rich or wellplaced men for money and material gains. Such girls who are called aristo babes live an affluent life style.

\section{Blocking/Sorting}

The linguistic processes used here are conversion and lexico-semantic extension. Block/blocking denotes a notorious and morally condemnable practice of bribing lecturers and members of staff in an institution and other places with money, gifts and sex to get pass marks, influence examination result or achieve a purpose. "Last September, I spent more than fifty thousand naira to block my lecturers." It is also called "sort/sorting."

\section{Zone/zoning}

In SBE, zone is an area of land or farm and to zone is to share an area of land or mark it out clearly. But in ENE, to zone is converted and extended to mean to rotate power, or relinquish the rights and power to do something, to compete for something, particularly political power, office and leadership, to a specific village, tribe or ethnic group or geo-political zone from the Ward, Local Government, State to Federal level. Zoning is the lexicalization of this political policy or practice, which are entrenched in political parties constitutions. "In conformity with power sharing and zoning principle, the President and Vice-presidential candidates have to be alternately picked from either north or south... the Zoning Principle of equity in representation and power sharing is now invariably adopted...”(Igbafe, 2006, p. 8).

\section{Quotarization (quota+rize+ation).}

Something akin to zoning, it is the lexicalization of "quota system" which operates in Nigeria, an official policy of sharing jobs, positions and resources not on the basis of merit or standard but on the basis of ethnic groups and federal structures to ensure peace and unity. Hence the term quotarization (Also noted in Igene, 1992, p.70).

\section{Godfatherism (god+father+ism)}

Godfatherism denotes the idea of having a godfather, the overbearing influence of a godfather, whether positive or negative, particularly in politics (Also see Igene, 1992:60).

\section{Sickler (sickle+er)}

Coined from sickly and sickle cell anaemia, a sickler is a sickly person; an SS-genotype carrier who often has crises. This is well-established in Nigeria medical usage and ENE.

\section{Cooler (cool+er)}

A coinage for a flask-like, plastic container of different sizes: small, medium and large used to preserve the temperature of cooked foods. It does not really cool down foods but rather keeps them warm or hot for a time.

\section{Face-to-face, also, face-me-I-face you}

A term use to describe (i) a type of building with a straight passage, often called parlour, and rooms at both sides facing one another; (ii) anything or situation that brings you face to face with another.

\section{Ghana-must-go bag}

In the 1970 s and 80 s when Nigeria economy and exchange power was very strong, when the Naira, Nigeria currency, exchanged at the same rate with the British Pounds, foreigners used to immigrate to Nigeria to do (odd) jobs. Ghanaians were a majority of them. However, Nigeria economy then collapsed and the millions of foreigners, mainly Ghanaians, in the country had to be asked to go. The phenomenon was tagged Ghana must go! A travaller's bag made of hessian or burlap material came into existence at that time and became ubiquitous. Ghanaians and other African country citizens were seen in groups carrying and pulling their personnel effects in many of this bag. So, the name Ghana-must-go became attached to the bag, which has remained its popular and notorious name till date. Now in Nigeria, Ghana-must-go bag is the most common and symbolic of bags. It is relatively affordable with stubborn texture, used to carry huge cash to banks and to bribe government officers. Hence the second and symbolic meaning of the bag is money, bribery and corruption. 


\section{(To) flash}

To beep a phone call: "Flash me when you arrive". When GSM and cell phones were introduced to Nigeria in August 2001, a beep usually comes with a shot ring and a flash of light on the screen; something reminiscent of a warning car flash light. So, Nigerians generally describe a beep call as a flash or to flash.

The examples under 2.1 above are by no means exhaustive. There are many others in ENE not accounted for in this paper.

\subsection{Compound Formations: Nigerian Innovations}

\section{Flash drive (flash+drive)}

It is used for SBE memory stick; coined from the light that normally flashes when it is on and the computer pot or drive into which it is inserted, hence flash drive.

\section{Prayer-warrior}

A term common with Pentecostal churches, meaning Christians who have the spiritual strength to pray at length and effectively: "Initially, when I joined the church, I was a prayer warrior" (Daily Sun 2008, p.36).

\section{Mr Lecturer}

It is common to hear instances of male lecturers who collect blocking, victimize their students and harass female students for sex, threatening to fail them if they refuse. Mr Lecturer is a derogatory term for a male lecturer who exhibits this tendency.

\section{Media-practitioner}

Reminiscent of medical practitioner/legal practitioner, this is used by some journalists to point out journalists, broadcasters and publicity professionals (Oguntuase, 2004, p.34).

\section{Pure-water}

It is used to denote water sold in a sachet or nylon or cellophane. Before the innovation of such packaged water, people used to drink all sorts of impure water that caused water-borne diseases. Pure water was then coined to draw attention to an innovation in water distribution as against the old dispensation of drinking contaminated water.

\section{Public dog}

It is a derogatory word for a loose girl or woman who sleeps with men indiscriminately. Someone who is easily won for sex just anywhere like dogs freely do when in heat.

\section{Home video}

Films produced in Nigeria by Nigerians and watched at home: "Nigerian home videos contrast with foreign films: American, Indian, British, Chinese films, etc. Such films keep people busy watching them at home; hence the label home video.

\section{Native-law}

Traditional marriage as contrasted with "church" (white garment) wedding:

\section{Home trouble/ family problem}

Nigerians believe in witches, wizards and other spiritual agents with their spiritual powers to impact positively or negatively on people's destiny, cause socio-economic retardation or progress, psychological problems, mysterious predicaments, etc. Home trouble or family problem is used to denote or connote this phenomenon and other intractable challenges and ill luck traceable to relatives or witches and wizards in one's family.

\section{No-go-area}

An of area or lace to be avoided; an issue or subject not open to (public) debate, discussion or changes; an already settled issue (Omonigho and Aziken, 2005, p.14).

\section{Walking stick}

A stick that elders or those who are ill or recuperating from injury use to support themselves while they walk; hence walking stick. Native British usage is staff.

\section{Bushmeat}

Meat from the forest; animals like antelope, rodents, etc and their flesh as contrasted with domestic meat like beef, mutton, chicken, etc. "Bushmeat" or "bushmu" is also used to describe rustic, unsophisticated girls who can easily be brainwashed for sex. "My bushmu /bushmeat will come to see me today."

\section{Carry-over}

This is popular with the educated people. Carry-over is a course of study in a higher institution which a student fails and so has to carry it forward to re-write in another examination (Igboanusi, 2002, pp.68, 69,73). 


\section{Federal Character}

A phrase for a deliberate government policy and official practice of governing to satisfy the interests of all the tribal and federating units in Nigeria by sharing employment political appointments, admissions, etc according to tribes, not necessarily by merit.

\section{Royal blessing}

Prayer for long life, goodwill, success, victory, etc by an Oba or traditional ruler, which is believed to be very potent. "Bendel Insurance Visit Oba of Benin for royal blessing" (Adodo, 2012).

\section{Open teeth}

A phrase for gap-toothed, having an opening in between the two front upper teeth, which gives a lovely smile.

\section{Sweet sixteen}

Young, seductive girls, sometimes in the company of older men, at times old enough to be there fathers and grandfathers.

\section{Aristo babe(s)}

Young girls who go out with sugar daddies and very rich men for monetary and material gains.

\section{Spirit husband/spirit wife}

A term used for the concept and belief in the possibility of one having a husband/wife in the spiritual world, an abnormal phenomenon that causes real sex in dreams and delayed marriage. SBE alternatives might be incubus and succubus.

\section{Cover cloth}

Cloth used to cover the body when asleep in bed. SBE closest word of the same function is duvet, but Nigerian cover cloth is not as thick and stuffed as a duvet.

\section{Woman wrapper}

This does not mean a wrapper that belongs to a woman, but a man who likes the company of women, a womanizer, especially a man who could or would do anything his wife or girlfriend says just to please her.

\section{Market Women}

Women who sell regularly as an occupation, usually in the open or in stores at major markets; sometimes constituting a populous group or section of society to deal with.

\section{Mommy-water/mammy water}

A word used in informal ENE to denote mermaid, or a female supernatural being believed to live in rivers, streams and oceans, having powers to harm or help mortals. Mommy-water is a leitmotif of one of Africa's music legends, Sir Victor Uwaifo's songs: Guitar Boy, if you see mommy water'ee, never, never you run away...

\section{House wife}

A full-time wife at home who does not do any formal job for which she is paid (monthly) salary.

\section{Eye-service}

Pretentious words, fake attitude, misleading actions and airs that one displays to impress someone, say a senior, a boss or an officer, etc only in their presence. The act of putting oneself forward to impress or show that one is active, dutiful, sympathetic or loyal when one is indeed not doing it sincerely, often used disapprovingly. It is also called notice-me.

\section{Kill-and-divide}

To kill and divide is very popular among politicians and civil servants. It means to have and share the spoils of office, to make money or get something somehow, usually illegally or questionably, and then share among those who facilitated it.

\section{Cash-and-carry}

SBE for a wholesale store where large goods are sold at moderate or low prices to buyers to take away themselves. In ENE, however, cash and carry means 'spend money to get something or influence decisions and results, bribe/bribery, rightly or wrongly' or 'if you spend cash, you get it.' When a process, situation, thing or someone is described as 'cash and carry', it means they are achievable, manipulable, winable if you offer enough money. "Nigerian politics is cash and carry."

\section{Long-leg}

A term used to express the concept, habit and scourge of using (undue) influence, tribalism, favoritism, bribery, connections, lobbying, etc justly or unjustly, to achieve a result, get a job or admission, etc. "It was long-leg he used to get a job in the Central Bank". 


\section{Native doctor}

A coinage analogous to a medical doctor or surgeon, used for a native healer who uses herbs and spiritual powers, not modern medical knowledge and tools.

\section{National cake}

A compound formation that invokes cake sharing in a social ceremony. National cake here is a symbol for state or national/federal resources and money to be shared to the federating units: Federal government, state and local government and then to individuals.

\section{Matrimonial home}

Marital life and home as well as the aura it generates, as opposed to outside it. It also connotes the sanctity and oneness of marriage. "No responsible person would bring their extra marital sex partner to their matrimonial home" (Jowitt, 1991, p.209). Also matrimonial bed: It is common to hear statements like "He has defiled his matrimonial bed".

\section{Big man}

Informally used to mean a well-placed man, a rich or influential person. It has nothing to do with physical size; for example, "his father is a big man in the Ministry of Finance."

\section{Area-boys}

A term that describes young (jobless) men that live in an area and sometimes constitute a nuisance: "Some area boys snatched her bag at that corner."

\section{Bottom power}

The deliberate use of sex by women for money, pleasure of life, to get a job or promotion and influence. (Also noted in Igboanusi, 2002, p.65; Iwegbue, 2011, p.20).

\section{(The) Nigerian factor}

This phrase as used in Nigeria does not really denote anything precisely or specifically. It is used to mean a range of typically Nigerian attitudes, practices, beliefs, etc which impede progress.

\section{African time}

Lateness common to Nigerians, believed to be ingrained in ancient African way of measuring time. Time used to be measured broadly as follows: early morning, late morning, noon, afternoon, evening and night; not in scientific fractions, seconds, minutes and hours, which are exact. So, if you put an event to kick off at 10.a.m., people may not start turning up until 12 noon, an objectionable habit that some still exhibit.

\section{Second burial}

This does not mean second interment, but it denotes a second ceremony with rituals done in the memory of a dead relation, usually for aged people, not for those who died young, in some Nigerian culture.

\section{Busy body}

A gossip, tale bearer, nose packer; one who is hyperactive (in tale-bearing).

\section{My wife}

Literally, it means my legally or otherwise married wife, mother of my child(ren). By cultural extension, when you say 'my wife,' you may actually be addressing your sister-in-law, or a close relation's wife. This concept and cultural bond is also extended to other kinship terms like my brother, sister, uncle, aunty, etc (Ntekim-Rex, p.596).

\section{Colour riot}

A compound word reminiscent of such standard ones as colour way, colour code, etc. Colour riot, until recently, was a derogatory term for a mismatch of dress colours. When one wears clothes with colours that do not match, then s/he and the event are described as colour riot. These days, people wear colour riot as a new trend in fashion.

\section{Yahoo boys}

A term used to describe young men who indulge in Internet fraud and fake business arrangements to dupe unsuspecting people on the Internet. When Internet was introduced to Nigeria in the late 1990s, Yahoo mail was, and is still, the most popular. Internet fraudsters send mail by yahoo to people's email inboxes all over the world introducing seductive business proposals which unsuspecting victims fall into and part away with their hard-earned money. The young men habitually live an affluent lifestyle from the money they rake from such Internet frauds. So, the popular derogatory name for them is Yahoo boys.

\section{High table}

A term that is entrenched in ENE, often used to denote those special guests of honour like the Chairman, charlady, moderator, etc and the seats and tables or platform arranged for them, which is usually separated from the main audience in a function or social event (Also in Jowitt, 1991). 
Lastly, we look at reduplication.

\subsection{Reduplication in Educated Nigerian English}

\section{Now-now}

It is used to convey urgency, emergency."Do you want me to leave now?" "Yes, leave now-now."

\section{Blow-blow}

Inf. ENE and children word for balloon, also used by adults.

Holy-holy

An informal derogatory word for those who pretend to be holy or clean when they are not: "They are not true Christians, but just doing holy-holy: they are holy-holy Christians."

\section{Cry-cry}

A word that adults use to describe a baby who cries often.

\section{Fast-fast}

It is at times used instead of British very quickly; common in informal ENE; for example,

Report to my office fast-fast.

\section{Tiny-tiny}

Common in informal ENE, it means very, very tiny; for example, I cannot read this tiny-tiny

letters of yours.

\section{Conclusion}

Educated Nigerians use lexicalization, compounding and reduplication, as shown above, to package and convey sociocultural ideas, concepts and experiences. The first two processes are more productive in this regard. Reduplication is least used of the three processes. Reduplication flourishes more in informal ENE and the other lower varieties of Nigerian English and Nigerian Pidgin, a language that has English and local languages as its parents. The structural pattern of reduplication in ENE is different from that of SBE reduplication. In ENE reduplication, the same base is often repeated, as in blow-blow. But in SBE, similar structures with some spelling or phonemic differences are often used, as in willy-nilly. What is common in the reduplicated elements is -illy, not *willy-willy, as in some of the Nigerian examples given above. The Nigerian types of compounding, lexicalization and reduplication mark out or characterize the lexical features of ENE. The examples treated in this paper are by no means exhaustive. Many examples exist in Nigerian English varieties that are not treated in this paper. However, the few examples above-depicted clearly show how social contexts and the urge to express socio-cultural ideas and concepts constrain educated Nigerians to manipulate and deploy the flexible dynamics of the language to produce lexical variations, which distinguish the morphology of Educated Nigerian English.

\section{References}

Adegbija, E. (1989). Lexico-semantic variation in Nigerian English. World Englishes 8(2), 165-177.

Adodo, I. (2012, February 3). News at 8.p.m”. Edo Broadcasting Service (EBS) Benin City.

Anikulapokuti, F. (1976). Colomentality. On Fela da great 1\&2 CD. Lagos: Universal Records 2010.

Anikulapokuti, F. (1978). Army arrangement. On Fela da great 1\&2 CD. Lagos: Universal Records 2010.

Bamiro, E. (1994). Lexico-semantic variation in Nigerian English. World Englishes 13(1), 42-61.

Banjo, A. (1970). The English language and the Nigerian environment". Journal of Nigeria English Studies Association 4(1), 51-60.

Banjo, A. (1996). Making a Virtue of Necessity: An Overview of the English Language in Nigeria. Ibadan: Ibadan University Press.

Brosnahan, L.F. (1958) English in Southern Nigeria. Journal of English Studies 39, 77-110.

Chomsky, M. (2011). Sociolinguistics (variationist) approach to language change. Retrieved from http:// Linguistic Forum Index. Org. May 2012.

Chomsky, N. A. (1965). Aspects of the theory of syntax. Cambridge: MIT Press.

Compound. Retrieved from http://grammar.abouts.com/od/c/g/compoudingterm.htm. 28 May 2012.

Concept. Retrieved from http://Stanford Encyclopedia of Philosophy. lato.Stanford.edu/entries/concepts. 28 May 2012.

Concept. Retrieved from Wikipedia free encyclopedia.org/wiki/concept. 28 May 2012.

Concept. Retrieved from American Heritage Dictionary. Htt:/educationyahoo.com/ reference dictionary/entry/conept 28 May 2012.

Daily Sun. (2006, May 10). Mighty men will fall in 2006, says new C and S leader. Daily Sun. p. 36. 
Crystal, D. (2009). A Dictionary of linguistics and phonetics. 6th ed. Oxford: Blackwell.

Effiong, C. O. (2011). Semantic contrasts in Educated Nigerian English.” In Udofot Inyang and Juliet Udoudom (Eds.) English Usage in Nigeria Since 1842 Patterns and Changes. Ikot Ekpene: Devconsort Books, 286-296.

Ekundayo, O. B. S. (2006). The concept of inraference in English as a second language: Examples from Nigerian English. (Unpublished M.A. thesis), University of Benin, Benin City, Nigeria.

Ekundayo, O. B. S. (2011). Nicknaming as morphological process: Implications for teaching and learning. A Paper Presented at the Annual ELTT Conference at Abeokuta. 13th to 15 July, 1-18.

Ekundayo, O. B. S. (2011). Intraference in Educated Nigerian English (ENE). A Ph.D. review of scholarship and justification of study presented to the Department of English and Literature, University of the Benin, August 2011.

Igbafe, P. (2006). Before the axe falls: History and the humanities in our national life: A valedictory lecture. Benin: University of Benin Press.

Igboanusi, H. (2002). A dictonary of Nigeria English. Ibadan: Encrownfit.

Igene, S. O. (1992). Lexis of Nigerian English. (Upublished M.A. thesis), University of Maiduguri, Maiduguri, Nigeria. Iwegbue, V.E. (2006). Sex and relationship in Tanure Ojaide's Matters of the Moment. (BA project) University of Benin, Benin City, Nigeria.

Jowitt, D. (1991) Nigeria English Usage: An introduction. Lagos: Longman.

Jowitt, D.. (2008). Varieties of English in Nigeria. An Inaugural Address. University of Jos, Jos, Plateau State, Nigeria.

Labov, W. (1963). The social motivation of sound change. Word 19, 273-309.

Labov, W. (1972). Language in the Inner City: Studies in the Black English Vernacular. Philadelphia: University of Pennsylvania Press.

Labov, W. (1994). Principle of Linguistic Change. Vol.I, Internal Factors. Oxford: Blackwell.

Labov, W.(2001).Principle of Linguistic Change. Vol.II, External Factors. Oxford: Blackwell.

Labov, W. (2010). Principle of Linguistic Change. Vol.II, Cultural Factors. Oxford: Blackwell.

Labov, W. Retrieved from Wikipedia, the free online encyclopedia_files. May 2012.

Labov, W. Retrieved from On African American English Vernacular@newlearning on line_files. May 2012.

Milroy, L. (2010). Sociolinguistics: Models and Methods. Retrieved from http:// variationist sociolinguistic .org. 20 July 2012.

Ntekim-Rex, Y.O. (2006). Nigerian English idioms usage: A reflection of diverse languages and cultures.” Literature, Language and National Consciousness: A festschrift in Honour of Thoe Vincent. In T. Akachi Ezeigbo and K. King Aribisala (Eds). Lagos: University of Lagos Press, 591-602.

Odumuh, A. O. (1980). The syntax and semantics of Nigerian English.” (Unpublished Ph.D. thesis), Ahmadu Bello University, Zaria, Nigeria.

Ogbulogo, C. (2005). Another look at Nigerian English. Covenant university public lecture series 1, 5.

Oguntuase, Bayo. (2004, June 24). Conventions of the language (2). Daily Sun, p. 22.

Osakwe, M. Tending, bending breaking vagabond English for global use needs. 24th Inaugural lecture, Delta State University, Abraka: Delta State University. Press, 2011.

Quirk, R. Greenbaum, S, Leech, G, \& Svartvik, J. (2003). A Comprehensive grammar of the English language. Standard ed. London: Longman.

Bayley, R..\& Ceil L. ed. (2007). Sociolinguistic variation: Theories, methods, and applications.Cambridge: Cambridge University Press.

Selinker, L. (1971). The psychologically relevant data of second-language learning. Psychology of Second language learning. In Paul Pimsleur, and Terence Quinn (Eds.). London: Cambridge University Press, 35-43.

Selinker, L. (1984). Interlanguage. In Richards, Jack C (Ed.). Perspective on Second Language Acquisition. London: Longman.

Sunday, A.B. (2008). Compound stress in educated Yoruba English. Papers in English and Linguistics, (PEL) l(9), 408.

Teilanyo, D. I. (2008). Neologisms in Nigerian English. Uyo Journal of Humanities 13, 28-51. 